\title{
The Danish version of Lymphoedema Functioning, Disability and Health Questionnaire (Lymph- ICF) for breast cancer survivors: Translation and cultural adaptation followed by validity and reliability testing
}

\section{Karin R Grarup, Nele Devoogdt \& Liv Inger Strand}

To cite this article: Karin R Grarup, Nele Devoogdt \& Liv Inger Strand (2019) The Danish version of Lymphoedema Functioning, Disability and Health Questionnaire (Lymph-ICF) for breast cancer survivors: Translation and cultural adaptation followed by validity and reliability testing, Physiotherapy Theory and Practice, 35:4, 327-340, DOI: 10.1080/09593985.2018.1443186

To link to this article: https://doi.org/10.1080/09593985.2018.1443186

Published online: 27 Feb 2018.

山 Article views: 202
Submit your article to this journal $\sqsubset$ 


\title{
The Danish version of Lymphoedema Functioning, Disability and Health Questionnaire (Lymph-ICF) for breast cancer survivors: Translation and cultural adaptation followed by validity and reliability testing
}

\author{
Karin R Grarup (10 ${ }^{\mathrm{a}}$, Nele Devoogdt ${ }^{\mathrm{b}}$, and Liv Inger Strand ${ }^{\mathrm{c}}$

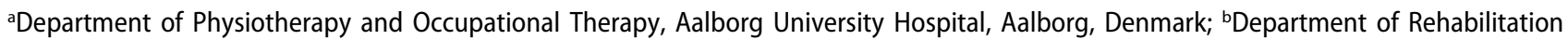 \\ Sciences, KU Leuven, University of Leuven, Leuven, Belgium; 'Department of Global Public Health and Primary Care, University of Bergen, \\ Bergen, Norway
}

\begin{abstract}
Purpose: To translate and culturally adapt the Lymphoedema Functioning, Disability and Health Questionnaire (Lymph-ICF) for breast cancer survivors with arm lymphedema into Danish and examine its content validity and reliability. Methods: (1) Translation and cultural adaptation was performed in 10 steps following international guidelines (International Society for Pharmacoeconomics and Outcome Research); (2) cognitive interviewing (step 7) was conducted in 15 women with breast cancer related arm lymphedema to explore understandability, interpretation, and cultural relevance; (3) after adjustments, content validity $(N=52)$ was explored by interviews; and (4) reliability $(N=50)$ examined by intraclass correlation coefficients (ICC) statistics and Cronbach alpha analysis. Results: Cognitive interviewing lead to an adapted and improved version of the translated questionnaire. Content validity was supported. Internal consistency (a) for all questions was .98 and ranged for the different domains between 0.92 and 0.97 . Test-retest reliability for the total score was highly satisfactory, ICC $=0.95$, standard error of measurement $(\mathrm{SEM})=4.5$ and smallest detectable change $=12.5$. ICC values for the domains ranged from 0.84 to 0.94 . SEM values differed for the domains, 6.4 (physical function), 5.7 (mobility activities), 7.09 (life and social activities), 9.1 (mental functions), and 10.2 (household activities). Conclusion: The translated and adjusted Lymph-ICF DK (Denmark) is reliable and valid, allowing for assessing selfreported impairments in function, activity limitations, and participation restrictions in Danish patients with breast cancer-related arm lymphedema.
\end{abstract}

\section{ARTICLE HISTORY}

Received 25 February 2017

Accepted 17 August 2017

Revised 3 July 2017

\section{KEYWORDS}

Lymphedema; breast cancer; Lymphoedema Functioning, Disability and Health Questionnaire; translation; cognitive interviewing; Danish version

\section{Introduction}

Breast cancer is the most common site of cancer amongst women worldwide (Ferlay et al., 2015) with a high incidence rate in Western and Northern European countries, including Denmark (Ferlay et al., 2013). Survival among patients with breast cancer in developed countries has improved over the last decades (Ferlay et al., 2015), probably due to implementation of organized mammography screening and changes in adjuvant treatment (Lietzen et al., 2011; Tryggvadóttir et al., 2010). At the end of 2013, 60,200 women and 270 men in Denmark were living with the diagnosis (Association of the Nordic Cancer Registries, 2015). Because of treatment, most frequently related to axillary lymph node dissection (ALND), many patients suffer from constraints in their arm and shoulder. Lymphedema is among the most commonly described impairments (Hidding et al., 2014), caused by damage to the lymphatic vessels and lymph nodes in connection with surgery and radiotherapy. The prevalence of breast cancer-related lymphedema varies with the treatment given (Hidding et al., 2014) and depends on the manner in which lymphedema is clinically detected and defined (Hayes et al., 2008, 2012; Rockson and Rivera, 2008). Findings suggest that approximately $20 \%$ of women surviving breast cancer will develop arm lymphedema (DiSipio, Rye, Newman, and Hayes, 2013; Hayes et al., 2012).

Methods of measurement used for patients with lymphedema often address clinical symptoms like swelling and pain. Volume measurements such as water displacement and circumferential measurements are commonly used to assess the efficacy of lymphedema treatment (International Society of Lymphology, 2013). However, several researchers have shown that volume and/or severity of lymphedema is poorly related to how patients perceive their physical and mental functioning

CONTACT Karin R Grarup karin.ravnsbaek.grarup@rn.dk @ Department of Physiotherapy and Occupational Therapy, Aalborg University Hospital, Aalborg, Denmark.

Color versions of one or more of the figures in the article can be found online at www.tandfonline.com/iptp.

(๑) 2018 Taylor \& Francis 
(Chachaj et al., 2010; Dawes, Meterissian, Goldberg, and Mayo, 2008; Fu and Kang, 2013; Morgan, Franks, and Moffatt, 2005). It is now realized that consequences of lymphedema should be assessed at different levels of a person's functioning (Viehoff et al., 2013). The test battery should also include a self-report measure.

The International Classification of Functioning, Disability and Health (ICF) (World Health Organization, 2013) is often used as a basis for functional status assessment, goal setting, treatment planning, and for outcome assessment. It provides a multiperspective, bio-psycho-social approach on functioning (World Health Organization, 2013).

The Lymphoedema Functioning, Disability and Health Questionnaire (Lymph-ICF) is a Dutch questionnaire based on the model and terminology of the ICF. The questionnaire consists of 29 questions, divided into five domains: physical function, mental function, household activities, mobility activities, and life and social activities. The questions are scored on a visual analogue scale (VAS) ranging from 0 to $100 \mathrm{~mm}$. In addition, there is a response option called "not applicable." The total score of the Lymph-ICF is equal to the sum of scores on the separate questions divided by the total number of answered questions. In addition, a sum score is determined for each of the five domains. Thus, the total score and the five domain scores each range between 0 and 100. According to the questionnaire developers, the Lymph-ICF can be used as a descriptive and evaluative tool to plan the treatment, monitor the patient's progress, and evaluate the treatment (Devoogdt et al., 2011). The Lymph-ICF has been found reliable and valid in patients with arm lymphedema after ALND for breast cancer (Devoogdt et al., 2011).

The patient's own perception of an adverse health condition is becoming an increasing concern among health personnel and health authorities. Currently, there is no patient-reported outcome measure available for patients with breast cancer-related lymphedema in Denmark. The aim of this study was therefore to translate and culturally adapt the original Dutch version of Lymph-ICF into Danish and examine its content validity and reliability.

\section{Materials and methods}

This study was conducted in four stages: (1) translation and cultural adaptation of the original Dutch version of Lymph-ICF into Danish (10 steps); (2) cognitive interviewing to explore understandability, interpretation, and cultural relevance of a pre-final Danish version (step 7); (3) content validation; and (4) reliability testing of the final Danish version.

According to the Ethics Committee in the region of North Jutland, Denmark, no approval from the Committee was necessary. All participants were given both oral and written information, and written informed consent was obtained. The project was approved by the Danish Data Protection Agency (protocol \#2008-58-0028).

The patients were recruited among patients referred to initial examination or undergoing treatment for breast cancer-related arm lymphedema at the Department of Physiotherapy and Occupational Therapy, Aalborg University Hospital. Exclusion criteria were palliative patients referred for treatment of arm lymphedema; patients with lymphedema isolated to the breast; patients with inadequate Danish language skills; and patients with cognitive deficits (e.g., dementia).

\section{Translation and cultural adaptation}

The translation and cultural adaptation was conducted according to international recommendations and principles of good practice, following 10 steps presented by the International Society for Pharmacoeconomics and Outcome Research (ISPOR) (Wild et al., 2005). Steps were (1) preparation, (2) forward translation, (3) reconciliation, (4) back translation, (5) back translation review, (6) harmonization, (7) cognitive debriefing, (8) review of cognitive debriefing results and finalization; (9) proofreading, and (10) final report. The steps of translation and cultural adaptation are shown in Table 1. Step 7: cognitive debriefing, being of particular importance for cultural adaptation, is described in more detail below.

\section{Cognitive debriefing of pre-final Danish version (step 7)}

To explore understandability, interpretation, and cultural relevance of the translation (Wild et al., 2005), the prefinal version of the Danish questionnaire was tested using cognitive interviewing techniques (Willis, Caspar, and Lessler, 1999; Willis and Artino, 2013) with patients drawn from the target population. Cognitive interviewing is a psychologically oriented method for empirically studying the way in which individuals mentally process and respond to survey questionnaires, investigating whether a question satisfies its intended purpose (Willis and Artino, 2013). Answering a survey question is divided into four basic cognitive processes: (1) comprehension of the question; (2) retrieval from memory information to 
Table 1. Overview of the 10 steps used for translation and cross-cultural adaptation (Wild et al., 2005).

\begin{tabular}{|c|c|}
\hline Steps & Description of how each step was performed \\
\hline Step 1. Preparation & $\begin{array}{l}\text { The developer of Lymph-ICF, Dr. Devoogdt, gave permission to the translation of Lymph-ICF into Danish and } \\
\text { offered assistance during the process. }\end{array}$ \\
\hline Step 2. Forward translation & $\begin{array}{l}\text { Three independent forward translations were performed. Two bilingual residents, native speakers of the } \\
\text { target (Danish) language, translated the questionnaire from Dutch to Danish. In addition, the project } \\
\text { manager, with a clinical background in lymphedema treatment, translated the English version of the } \\
\text { questionnaire to Danish. }\end{array}$ \\
\hline Step 3. Reconciliation & $\begin{array}{l}\text { The project manager met with the translators to compare and discuss differences between the three } \\
\text { translations in order to reach consensus on a single reconciled version. Ambiguities and discrepancies } \\
\text { between the translations were discussed with Dr. Devoogdt. }\end{array}$ \\
\hline Step 4. Back translation & $\begin{array}{l}\text { A bilingual Dutch physiotherapist performed the back translation into Dutch of the reconciled Danish } \\
\text { translated version. She was fluent in Danish, had a Master of Science degree, and had former experience in } \\
\text { translation of questionnaires, but no knowledge of Lymph-ICF prior to the translation. }\end{array}$ \\
\hline Step 5. Back translation review & $\begin{array}{l}\text { The project manager and the back translator reviewed the back translation against the source instrument to } \\
\text { identify any discrepancies between the two versions. Dr. Devoogdt was contacted for clarification. }\end{array}$ \\
\hline $\begin{array}{l}\text { Step 6. Harmonization between different } \\
\text { language versions }\end{array}$ & $\begin{array}{l}\text { There was only a Dutch and an English version of the questionnaire, produced by the developers (Devoogdt } \\
\text { et al., 2011), at the time of our translation into Danish. Apparent discrepancies between the three language } \\
\text { versions were discussed with the developer. }\end{array}$ \\
\hline Step 7. Cognitive debriefing & $\begin{array}{l}\text { Cognitive Interviewing techniques (Willis, Caspar, and Lessler, 1999; Willis and Artino, 2013) were used in } 10 \\
\text { patients, drawn from the target population, to explore understandability, interpretation, and cultural } \\
\text { relevance of the pre-final version of the Danish questionnaire. The project manager performed the interviews. }\end{array}$ \\
\hline $\begin{array}{l}\text { Step } 8 \text {. Review of cognitive debriefing } \\
\text { results and finalization }\end{array}$ & $\begin{array}{l}\text { The project manager reviewed the results from cognitive interviewing and identified desirable translation } \\
\text { modifications. Dr. Devoogdt approved the modifications, and the translation was finalized. To validate the } \\
\text { adjusted version the project manager conducted another round of cognitive interviewing, including five } \\
\text { patients. }\end{array}$ \\
\hline Step 9-10. Proofreading and final report & $\begin{array}{l}\text { An experienced lecturer in the Danish language at Senior High proofread the final Danish (DK) version of } \\
\text { Lymph-ICF, in order to correct any remaining spelling or grammatical errors. A report was written of the } \\
\text { choices made throughout the translation process. The questionnaire was called Lymph-ICF DK. }\end{array}$ \\
\hline
\end{tabular}

prepare an answer; (3) decision processes influencing the respondent's response; and (4) the response process, in which the respondent produces an answer to the survey question (Willis, Caspar, and Lessler, 1999; Willis and Miller, 2011). By focusing explicitly on these processes, both overt, observable cognitive processes, as well as covert ones that are normally hidden, can be studied. By using cognitive interviewing, we could detect lack of comprehension and structural or logical problems in the translated questionnaire (Willis, Caspar, and Lessler, 1999), which, if undetected, could lead to missing or inaccurate data (Wild et al., 2005).

\section{Data collection}

For 3 months, from December 2014 to March 2015, all eligible patients were invited to participate in cognitive interviewing. Of 13 patients, 11 agreed to participate, while 2 declined. One patient had merely lymphedema of the breast and was therefore excluded. Since the questionnaire was self-administered, the respondents were asked to complete it independently. Cognitive interviewing with retrospective probing (follow-up questions) was conducted immediately afterward and the interviews were audiotaped with the permission of the respondents. Letting the respondents complete the questionnaire before the interview can help determine their ability to complete the questionnaire unaided and to follow sequencing instructions (Willis, Caspar, and Lessler, 1999; Willis and Artino, 2013). The interviews ended with general questions about the questionnaire as a whole.

\section{Analyses}

The project manager and BG, a lecturer in physiotherapy who was experienced in the method of cognitive interviewing, listened to the audiotapes and performed independent analysis and coding. In addition to the tapes, the completed questionnaires were analyzed to identify inadequate and/or missing answers. Identified problems were coded in a Respondent Problem Matrix (Conrad and Blair, 1996; Conrad, Blair, and Tracy, 1999). Consensus was reached through dialog. When considering questions or structural problems for revision, we focused on problems that emerged repeatedly across interviews as well as problems that we judged could threaten data quality severely (Willis, Caspar, and Lessler, 1999).

\section{Content validity}

\section{Participants and data collection}

All patients, referred to treatment for breast cancerrelated arm lymphedema at the Department of Physiotherapy and Occupational Therapy at Aalborg University Hospital from July 2015 to November 2016, were asked to participate in a study of content validity and reliability of the final Danish version of 
Lymph-ICF. As recommended by De Vet, Terwee, Mokkink, and Knol (2011), at least 50 patients should be included in the examination of reliability and validity. Out of 55 eligible patients, 52 agreed to participate. During the initial examination at the hospital department, demographic and clinical data were collected including age, occupation, type and date of breast surgery, type of adjuvant treatment (i.e., radiotherapy, chemotherapy, or hormonal therapy), hand dominance, region of arm lymphedema, and duration of lymphedema. After filling out the Danish questionnaire, the patients were asked the following questions related to content validity (Devoogdt et al., 2011): (1) Is each question of the questionnaire understandable? (2) Is the scoring system clear? (3) Does the questionnaire mention all complaints related to your lymphedema? Scoring alternatives were yes and no. Positive (yes) and negative responses (no) were counted, and patients' explanations on the negative answers were discussed in a group of four physiotherapists specialized in lymphedema.

\section{Reliability testing}

Cronbach alpha analysis was used to determine internal consistency of the entire questionnaire and of each domain. A value $>0.70$ was considered satisfactory (De Vet, Terwee, Mokkink, and Knol, 2011). To examine test-retest reliability the patients who had participated in the content validity study, received a second copy of the Danish Lymph-ICF to fill out at home two days later at the same time of day and return it to the department by letter. Test-retest reliability was initially examined by descriptive data (mean, SD), and by inspecting test-retest scatterplots. Difference between scores was examined by paired samples $t$-tests. Intraclass correlation coefficients (ICC $[1,1]$ ) of the total score of the Lymph-ICF DK and of the five domains were calculated as measures of relative reliability. ICC values $\geq 0.70$ were considered satisfactory, the higher value the better (De Vet, Terwee, Mokkink, and Knol, 2011; Terwee et al., 2007). As a measure of absolute reliability, standard error of measurement (SEM) was calculated, being the estimated within-subjects standard deviation of repeated measurements (Carter, Lubinsky, and Domholdt, 2011; Mokkink et al., 2010). SEM is expressed in the unit of the measurement tool. The smallest detectable change (SDC), defined as change beyond measurement error, was calculated by 2.77 SEM to give an estimate of the smallest change in score that, with $95 \%$ confidence, can be interpreted as a real change, being above measurement error in an individual (De Vet, Terwee, Mokkink, and
Knol, 2011; Terwee et al., 2007). A Bland-Altman plot was constructed for the total score of the Lymph-ICF DK, illustrating variability in scores from test to retest by limits of agreement and mean scores, reflecting potential systematic drift in data (Bland and Altman, 1986).

\section{Results}

\section{Translation and cultural adaptation}

Lymph-ICF was translated into Danish as described in Table 1. The back translation confirmed semantic and conceptual equivalence with the original questionnaire as most questions were almost identical, but the back translation gave rise to adjustments of title, two subheadings and introduction on the front page. An adjusted back translated version was sent to Dr. Devoogdt in order to ensure conceptual equivalence. She recommended that subheadings were somewhat revised to follow the terminology for domains in the Danish ICF handbook.

\section{Cognitive debriefing of pre-final Danish version}

Ten female patients, aged $46-83$ years, participated in cognitive interviewing. Table 2 shows characteristic of the patients. The two coders mostly identified the same problems, examples shown in Table 3. The respondents reported that overall the questions were relevant and easy to understand. Two questions (question 4 and 27) needed minor revisions. Some problems were revealed related to the decision process of scoring. The test developer had encountered similar problems and recommended some verbal information prior to scoring the questionnaire to avoid misunderstandings. However, the main problem was the VAS. Three of 10 patients misunderstood the scale, giving rise to response errors. Furthermore, one patient misunderstood the response option "not applicable." We suggested that a numeric rating scale (NRS) was applied rather than a VAS, as we found support for this in a review study (Hjermstad et al., 2011). Dr. Devoogdt agreed on this transition, implying that each question is scored on a $0-10$ scale. The total score on the Danish version is calculated as follows: (sum of scores on the 29 questions divided by the total number of answered questions) $\times 10$. In the same way, a sum score is determined for each of the five domains. The total score and the domain scores range from 0 to 100 . The introduction to the scoring system on the front page of the questionnaire was further developed and adapted to the NRS. To clarify the graduation on the scale, the part 
Table 2. Characteristics of patients participating in different parts of the study.

\begin{tabular}{|c|c|c|}
\hline \multirow[b]{2}{*}{ Characteristics } & \multicolumn{2}{|c|}{ Participants } \\
\hline & $\begin{array}{l}\text { Validity and reliability }{ }^{1} \\
n=52\end{array}$ & $\begin{array}{c}\text { Cognitive interviewing } \\
n=15\end{array}$ \\
\hline Age, mean (SD) & $61(12.4)$ & $61.5(9.7)$ \\
\hline Gender female, $n(\%)$ & $52(100)$ & $15(100)$ \\
\hline Body mass index $\left(\mathrm{kg} / \mathrm{m}^{2}\right)$, mean $(\mathrm{SD})$ & $27.7(5.4)$ & \\
\hline Working, $n(\%)$ & $17(33)$ & $6(40)$ \\
\hline Early retirement/retirement, $n$ (\%) & $26(50)$ & $8(53)$ \\
\hline Sick leave or unemployed, $n(\%)$ & $9(17)$ & $1(7)$ \\
\hline \multicolumn{3}{|l|}{ Breast surgery } \\
\hline Mastectomy, $n(\%)$ & $36(69)$ & $8(53)$ \\
\hline Breast-conserving surgery, $n$ (\%) & $16(31)$ & $7(47)$ \\
\hline Surgery on the dominant side, $n(\%)$ & $28(54)$ & \\
\hline \multicolumn{3}{|l|}{ Adjuvant treatment } \\
\hline Radiotherapy, $n$ (\%) & $50(96)$ & $15(100)$ \\
\hline Chemotherapy, $n$ (\%) & $36(69)$ & $13(87)$ \\
\hline Antihormonal therapy, $n$ (\%) & $39(75)$ & $13(87)$ \\
\hline \multicolumn{3}{|l|}{ Region of arm lymphedema } \\
\hline Upper arm, $n(\%)$ & $9(17)$ & $0(0)$ \\
\hline Lower arm, $n$ (\%) & 7 (14) & $1(7)$ \\
\hline Total arm, $n(\%)$ & $36(69)$ & $14(93)$ \\
\hline Hand lymphedema, $n(\%)$ & $29(56)$ & $8(53)$ \\
\hline Presence of lymphedema in months, median (IQR) ${ }^{2}$ & $15.5(58)$ & $24(31)$ \\
\hline Lymphedema volume $(\mathrm{ml})$, median $(\mathrm{IQR})^{2}$ & $445(504)$ & \\
\hline
\end{tabular}

${ }^{1}$ Two patients lacking in test-retest analysis.

${ }^{2}$ Interquartile range

Table 3. Examples of coding problems detected by cognitive interviewing.

\begin{tabular}{|c|c|c|c|}
\hline Problem type $\begin{array}{c}\text { Response } \\
\text { stage/process: } \rightarrow\end{array}$ & Understanding & Retrieval/decision & Response formatting \\
\hline $\begin{array}{l}\text { Lexical problems } \\
\text { Not knowing the meaning of } \\
\text { words or how to use them. }\end{array}$ & & $\begin{array}{l}\text { One respondent had difficulty deciding how } \\
\text { to answer question } 4 \text {, because she was } \\
\text { unsure as to what constitutes reduced } \\
\text { strength: a subjective feeling or an objective } \\
\text { measurement? }\end{array}$ & \\
\hline Inclusion/omission problems & & Difficulty deciding how to answer questions & \\
\hline $\begin{array}{l}\text { Problems determining } \\
\text { whether certain concepts } \\
\text { are to be considered within } \\
\text { the scope of the question. }\end{array}$ & & $\begin{array}{l}12 \text { and } 15 \text { since cleaning and gardening } \\
\text { cover several tasks of varying difficulty. } \\
\text { Respondents who had help (e.g., cleaning } \\
\text { lady, gardener, spouse), because specific } \\
\text { tasks exacerbated their symptoms, had } \\
\text { doubts as to answer "not applicable" or to } \\
\text { give an answer that reflected restriction } \\
\text { forcing them to get help in the first place. }\end{array}$ & \\
\hline $\begin{array}{l}\text { Temporal problems } \\
\text { Problems involving the time } \\
\text { period to which the } \\
\text { question applies. }\end{array}$ & & & $\begin{array}{l}\text { Variation (e.g., sometimes, } \\
\text { periodically) in symptoms } \\
\text { and limitations cannot be } \\
\text { reported }\end{array}$ \\
\hline $\begin{array}{l}\text { Logical problems } \\
\text { Problems involving } \\
\text { connectives like "and" and } \\
\text { "or," negation, } \\
\text { complementarity. } \\
\text { Problems associated with, } \\
\text { e.g.,false presuppositions or } \\
\text { involving contradictions in } \\
\text { a question. }\end{array}$ & & $\begin{array}{l}\text { Gardening and sunbathes are seasonal } \\
\text { activities. Respondents pointed out that this } \\
\text { opposed being asked to choose an answer } \\
\text { according to their complaints during the last } \\
\text { two weeks. Hence, the answers off-season } \\
\text { would not reflect the restrictions that they } \\
\text { had in-season. }\end{array}$ & \\
\hline $\begin{array}{l}\text { Computational problems } \\
\text { Residual category }\end{array}$ & $\begin{array}{l}\text { Several respondents misunderstood the } \\
\text { VAS. They answered with yes or no as if the } \\
\text { scale was dichotomous, or wrote detailed } \\
\text { answers to explain about intensity. One } \\
\text { elderly patient misunderstood the response } \\
\text { option "not applicable." } \\
\text { Question } 27 \text { "Can you wear the clothes you } \\
\text { like to wear?" was not understood as } \\
\text { intended. }\end{array}$ & & \\
\hline
\end{tabular}


of the sentence that initiated the questions 12-29: "Can you ...?" was changed to: "To what extent are you able to ...?"

It was also decided to give the patients a short verbal introduction before they filled out the questionnaire. After the revision, the project manager conducted an additional round of cognitive interviewing with five new patients from the target group to test the adjusted Danish questionnaire. All the patients were found to readily understand how to use the NRS and the response option "not applicable," and further revision was not necessary. The final Danish version of Lymph-ICF, called Lymph-ICF DK, is presented in the Appendix.

\section{Content validity}

All 52 patients (Table 2) who completed the first questionnaire answered the questions about content validity of the Danish version of Lymph-ICF. All found the questions understandable, and the scoring system clear. All but one patient found that all their complaints were addressed in the questionnaire. One patient mentioned that she had a feeling of discomfort in her arm, as being sunburned, and this symptom was not covered in the questionnaire. The possibility to add comments to the separate answers was suggested by a few patients.

\section{Reliability testing}

Internal consistency of Lymph-ICF scores was satisfactory. The Cronbach alpha coefficient for all questions was .98 and ranged for the different domains between 0.92 and 0.97 (Table 4). While 52 patients (Table 2) scored the questionnaire at baseline, 2 did not return the second questionnaire and could not be included in the test-retest analyses. The scatterplot over test-retest scores for the total score showed that the data were neatly distributed in a narrow cigar shape along the diagonal (the diagonal reflecting complete concordance), suggesting a strong correlation and small measurement error (Pallant, 2010). The scores were spread from 2 to 88 on the scale (Figure 1). The scatterplots of data from the physical function domain and for the two domains related to mobility activities and life and social activities also indicated strong correlations and relatively small measurement errors. For these three domains, the scores covered most of the scale, from 0 to 100,0 to 91 , and 0 to 94 , respectively. The range of scores for the mental function domain was mostly on the lower end of the scale, $20 \%$ of patients scoring 0 , meaning that they did not experience any emotional impact of the lymphedema at all. The distances of some data points from the diagonal were rather large, suggesting larger measurement error for this domain. This was also the case for the household domain with scores spread from 0 to 90 on the scale. The ICC values of the total scale (0.95) as well as for the five domains were satisfactory (Table 4), ranging from 0.84 (household activities) to 0.94 (mobility activities). Measurement error by SEM for the total score was 4.5 and by $\mathrm{SDC}=12.5$. Accordingly, a change of at least $12.5 \mathrm{can}$ be considered a real change. Two domains (mental function, household activities) had considerable measurement errors with SDC values of 9.1 and 10.2, respectively.

The Bland-Altman plot (Figure 2) demonstrated a small systematic drift in data between test and retest $(-1.03)$, and the $95 \%$ limits of agreement was +11.4 to -13.5 . There was a trend of patients with low scores at the first test (hospital) to score even lower at the second test (home), but the opposite for patients with high initial scores, tending to score somewhat higher at the second test. The SDC value of 12.5 as compared to the limits of agreement values seems to be an acceptable approximation of the measurement error that has to be taken into consideration when judging change in individual patients.

\section{Discussion}

In this study, we obtained a Danish version of LymphICF, called Lymph-ICF DK, following international

Table 4. Test-retest reliability and internal consistency of the total and domain scores of the Lymph-ICF DK.

\begin{tabular}{|c|c|c|c|c|c|c|c|c|}
\hline & \multicolumn{2}{|c|}{ Mean (SD) } & \multirow[b]{2}{*}{$P$-value } & \multirow[b]{2}{*}{$a$} & \multirow[b]{2}{*}{ ICC } & \multirow[b]{2}{*}{$95 \% \mathrm{Cl}$} & \multirow[b]{2}{*}{ SEM } & \multirow[b]{2}{*}{ SDC } \\
\hline & Test & Retest & & & & & & \\
\hline Lymph-ICF DK - total score & 33 (19) & $34(22)$ & 0.258 & .98 & .95 & .92 to .97 & 4.51 & 12.5 \\
\hline Physical function score & $44(24)$ & $42(25)$ & 0.196 & .97 & .93 & .88 to .96 & 6.40 & 17.6 \\
\hline Mental function score & $23(26)$ & $22(26)$ & 0.589 & .93 & .88 & .79 to .93 & 9.12 & 25.3 \\
\hline Household activities score & $30(25)$ & $34(25)$ & 0.035 & .92 & .84 & .73 to .90 & 10.21 & 28.3 \\
\hline Mobility activities score & $31(21)$ & $33(24)$ & 0.094 & .97 & .94 & .89 to .96 & 5.69 & 15.8 \\
\hline Life and social activities score & $30(24)$ & $33(27)$ & 0.105 & .96 & .92 & .87 to .96 & 7.09 & 19.6 \\
\hline
\end{tabular}

$P$-value based on paired $t$-test.

$\mathrm{SD}=$ standard deviation, $\mathrm{a}=$ Cronbach alpha coefficient, $\mathrm{ICC}=$ intraclass coefficient, $\mathrm{Cl}=$ confidence interval, $\mathrm{SEM}=$ standard error of measurement, $\mathrm{SDC}=$ smallest detectable change. 

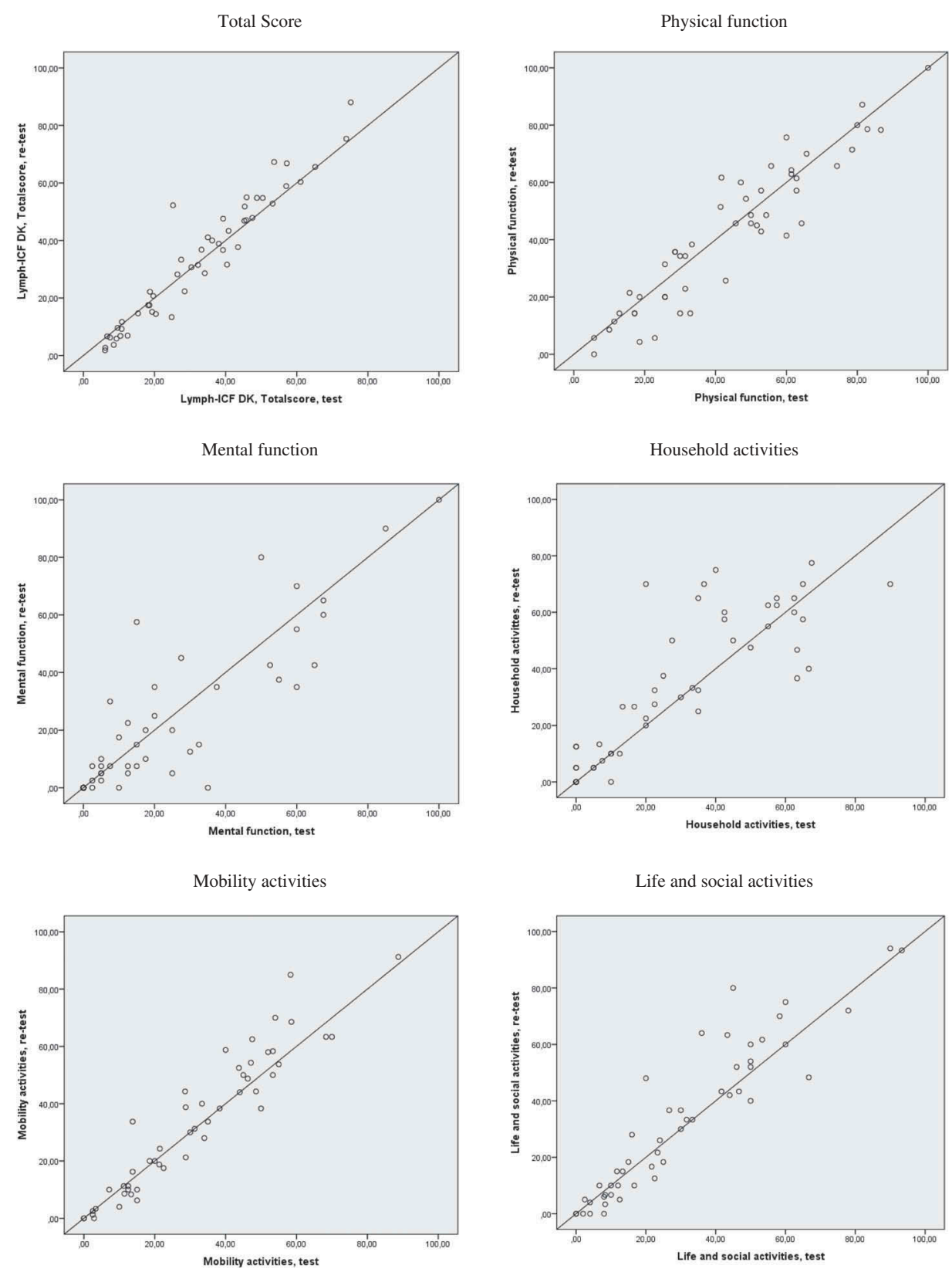

Figure 1. Scatterplots of Lymph-ICF DK total score and domain scores at test and retest.

recommendations for the translation and cultural adaptation process (Wild et al., 2005). Cognitive interviewing was found to be a valuable method for identifying problems in the translated questionnaire, leading to an improved, final version that demonstrated highly satisfactory content validity and reliability.

Our decision of changing the scale of the LymphICF DK was supported by a systematic review (Hjermstad et al., 2011), finding that the NRS had better compliance in 15 of 19 studies when comparing NRS, VAS, and verbal rating scale. In 11 studies, the NRS was the recommended scale based on higher compliance rates, better responsiveness, ease of use, and good applicability relative to VAS. Scores of the NRS and VAS were also found to correlate highly, which was important in making the transition of the scale possible. An additional round of cognitive interviewing, after transition from VAS to NRS, showed that all patients readily understood how to use the NRS. Thus, it appears that the transition from VAS to NRS reduces the risk of response bias.

Despite rigorous translation and cross-cultural adaption, it is recommended to ensure that the translated version demonstrates satisfactory measurement properties. In this study, we assessed content validity and reliability of the translated version. In order to be able 


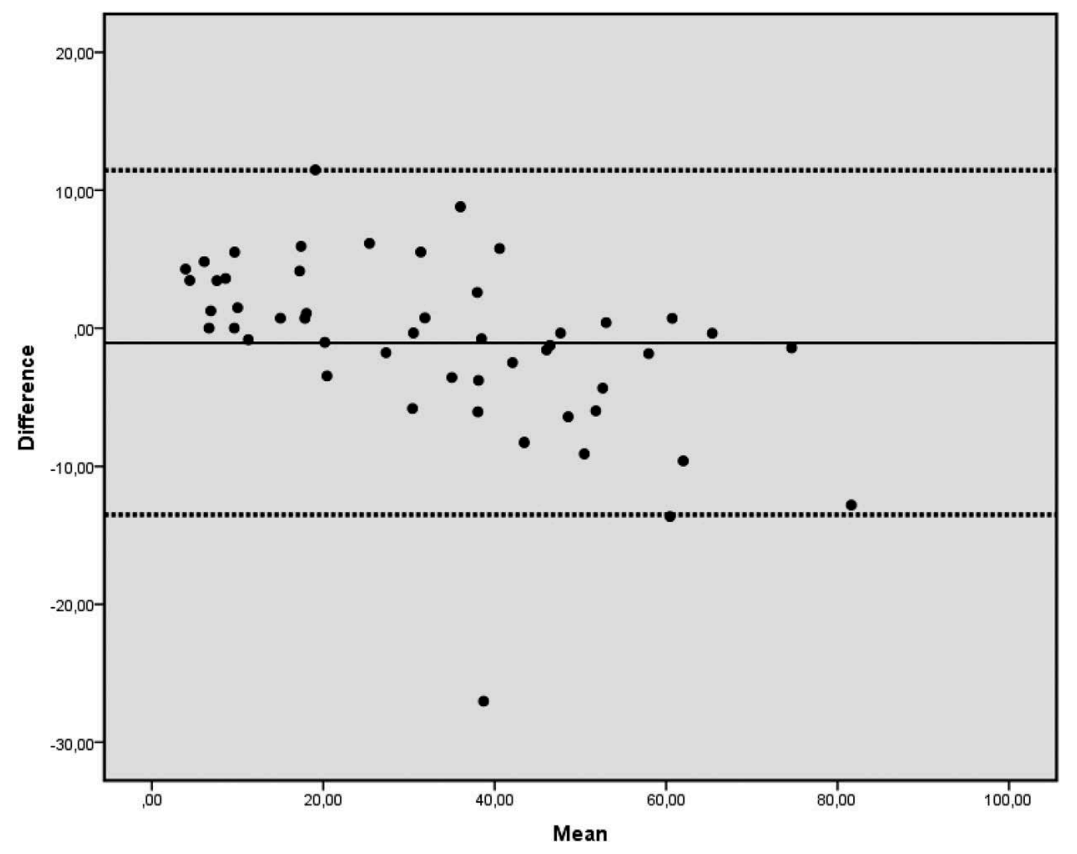

Figure 2. Bland-Altman Plot showing the intra-individual differences between Lymph-ICF DK total scores at test-retest at the $Y$-axis, against the mean change scores at the $X$-axis $(n=50)$. The central black line represents the mean difference in scores of repeated measurements (-1.03), and the dotted black lines represent the 95\% limits of agreement (upper: 11.44, lower: -13.50$)$.

to compare our results with those of the original questionnaire, the tests were performed in a similar manner, as recommended by Beaton, Bombardier, Guillemin, and Ferraz (2000).

To investigate content validity of the Danish version, we used the same three questions as was used by the authors of the original version of Lymph-ICF, and cross-cultural validity was supported as similar results were obtained across the two languages and cultures. Importantly, all patients (100\%) found the scoring system of Lymph-ICF DK clear, while $88 \%$ of the respondents found the scoring system of the original questionnaire clear. This difference could be explained by the transition of the scale from a VAS to NRS in the Danish version, as well as by the change of the sentence initiating questions 12-29. Fifty-one patients (98\%) found that all their complaints were addressed in the Danish questionnaire, as opposed to $85 \%$ of the patients in the test of the original questionnaire. One explanation to this difference could be that content validity was investigated with a written questionnaire in the test of the original questionnaire, while we interviewed the patients and were therefore able to ask the patients to clarify in case of ambiguities.

Both the original and the Danish version of LymphICF had satisfactory internal consistency with Cronbach alpha values $>0.70$ ranging from 0.72 to 0.92 and 0.92 to 0.98 , respectively. Cronbach alpha levels $>0.95$ may imply item redundancy, indicating that the scale possibly could contain fewer items, making it more feasible for clinical use (De Vet, Terwee, Mokkink, and Knol, 2011; Terwee et al., 2007). Our aim was not to develop a new scale, but to translate and culturally adapt the original questionnaire. A factor analysis for dimensionality could not be performed due to our small sample size (De Vet, Terwee, Mokkink, and Knol, 2011).

Test-retest reliability of Lymph-ICF DK by ICC values was highly satisfactory for the total score (0.95), but also satisfactory for the five domains (0.84-0.94). ICCs and measurement error by SEM for the total score, the physical function domain, and the mental function domain of the Danish version were quite similar to the results of the original questionnaire, while the Danish version had somewhat higher ICCs and smaller SEMs for the domains mobility activities, and life and social activities. In contrast, the Danish version had lower ICC and larger SEM for the domain of household activities. Two domains - mental function, and life and social activities in the original questionnaire - had rather large measurement errors with SEM values of 9.0 and 12.5, respectively. This was also the case for the Danish version, where SEM for mental function domain was 9.1 and SEM for the domain related to household activities was 10.2. Substantial changes on these scales will therefore be necessary to be able to document real change, taking measurement error into account. 
A Turkish version of Lymph-ICF was published in 2016 (Kostanoglu, Hosbay, and Tarak, 2016). Besides the Dutch and English versions, produced by the questionnaire developers, this was the first translated version into another language. It was adapted from the English version of Lymph-ICF. Thirty patients were included in reliability testing examined by ICC statistics and Cronbach alpha analysis. The authors reported satisfactory internal consistency with Cronbach alpha values ranging from 0.89 to 0.99 and adequate to excellent test-retest reliability with ICC values ranging from 0.80 to 0.99 . Measurement error by SEM and SDC was not reported. There are several differences in conditions for examining test-retest reliability of the Turkish version as compared to the Dutch and Danish versions, which could influence the test results. All patients completed the Turkish version under supervision at both test and retest, whereas the Dutch and Danish questionnaires were completed without supervision since the Lymph-ICF is meant to be self-administered. Furthermore, the time interval between test and retest was 7 days for the Turkish version and 2 days for the Dutch and Danish versions. In addition, the Turkish study included only patients with mild to moderate lymphedema, while patients with severe lymphedema were also included in the Dutch and Danish studies. This means that the basis for comparing validity and reliability is not straightforward across versions.

Surprisingly, $20 \%$ of the patients in our study did not report any mental impact of having lymphedema in connection with breast cancer at all, and many had a low score on this domain, which is not consistent with our clinical experience. Lymphedema was also shown in a Danish cohort study to have a substantial emotional effect on women treated for breast cancer, adversely affecting quality of life (Vassard et al., 2010). This can be a cross-cultural issue as Danish patients may attach a different meaning to the word mental than is intended. In a Danish context, mental is associated with cognitive functions rather than with emotions that can explain why they did not identify themselves with such problems. As subheadings must follow domains in the Danish ICF-handbook, the word was maintained, but is still a matter of concern.

\section{Strengths and limitations of the study}

In this article, we have documented that Lymph-ICF was translated and culturally adapted to Danish, using a rigorous procedure consistent with international guidelines. This is important since poorly translated instruments threaten the validity of research data (Wild et al.,
2005). A particular strength of our study was that the pre-final version of the Danish questionnaire was tested for understandability, interpretation, and cultural relevance by cognitive interviewing. It gave insight into how the respondents interpreted, understood, and responded to the questions and led to an improved version of the Danish questionnaire.

In the study of reliability, we followed the recommended methods and preferred statistical analyses outlined by the COSMIN group (Mokkink et al., 2010). A sufficiently high sample size of 50 patients was included to obtain a solid estimate of reliability (De Vet, Terwee, Mokkink, and Knol, 2011; Terwee et al., 2007).

Content validity of a questionnaire implies that the questions should be both relevant and comprehensive for the construct to be measured. A limitation of our study was that the three questions we used to examine content validity mainly focused on comprehensiveness and not on relevance. We chose this approach to be able to compare our results with those of the original questionnaire. However, as we used cognitive interviewing to explore understandability, interpretation, and cultural relevance of the pre-final version, we think relevance was adequately addressed.

Another limitation of the study was that forward and backward translators were not professional translators as recommend by ISPOR (Wild et al., 2005). We could not meet this requirement; still we judge that the translation was performed in a competent and meticulous way.

\section{Conclusion}

Evidence was provided that the Lymph-ICF DK is reliable and valid. The final version was found easy to understand and score by the target users, and the questionnaire was shown to include the most relevant questions about functioning and disability. The LymphICF DK is applicable and recommended for use in research and clinical practice for assessing self-reported impairments in function, activity limitations, and participation restrictions in Danish patients with arm lymphedema related to breast cancer. Further research on responsiveness of the Lymph-ICF DK is needed.

\section{Acknowledgments}

The authors thank all the women with breast cancer-related lymphedema who willingly participated in this study. The authors would also like to thank the translators for their help, Lone G. Laursen, physiotherapist at Department of Physiotherapy and Occupational Therapy at Aalborg University Hospital, for data collection assistance, and 
associate professor Bo Grarup for coding a part of the cognitive interviews and for help with statistics. Finally, the corresponding author would like to thank Dr. Nele Devoogdt, who found time to discuss results of our research project. Her comments were of great value for us.

\section{Declaration of interest}

The authors report no declarations of interest.

\section{ORCID}

Karin R Grarup (D) http://orcid.org/0000-0001-5000-3232

\section{References}

Association of the Nordic Cancer Registries 2015 Cancer Statistic Fact sheets Denmark - Breast http://www-dep. iarc.fr/NORDCAN/English/StatsFact.asp? cancer= 200\&country $=208$. Accessed 20 Feb 2016.

Beaton DE, Bombardier C, Guillemin F, Ferraz MB 2000 Guidelines for the process of cross-cultural adaptation of self-report measures. Spine 25: 3186-3191.

Bland JM, Altman DG 1986 Statistical methods for assessing agreement between two methods of clinical measurement. Lancet 1: 307-310.

Carter E, Lubinsky J, Domholdt E 2011 Rehabilitation Research: Principles and Applications, 4th ed St. Louis, MO, Elsevier Saunders.

Chachaj A, Malyszczak K, Pyszel K, Lukas J, Tarkowski R, Pudelko M, Andrzejak R, Szuba A 2010 Physical and psychological impairments of women with upper limb lymphedema following breast cancer treatment. PsychoOncology 19: 299-305.

Conrad F, Blair J 1996 From impressions to data: Increasing the objectivity of cognitive interviews. In Proceedings of the Section on Survey Research Methods, Annual Meetings of the American Statistical Association, pp 1-10. Alexandria, VA: American Statistical Association.

Conrad F, Blair J, Tracy E 1999 Verbal reports are data! A theoretical approach to cognitive interviews. In: Proceedings of the Federal Committee on Statistical Methodology Research Conference, 1999 Tuesday B Sessions, pp 11-20. Arlington, VA.

Dawes DJ, Meterissian S, Goldberg M, Mayo NE 2008 Impact of lymphoedema on arm function and health-related quality of life in women following breast cancer surgery. Journal of Rehabilitation Medicine 40: 651-658.

De Vet HC, Terwee CB, Mokkink LB, Knol DL 2011 Measurement in Medicine, Practical Guide A 3rd Cambridge, Cambridge University Press.

Devoogdt N, Van Kampen M, Geraerts I, Coremans T, Christiaens MR 2011 Lymphoedema Functioning, Disability and Health Questionnaire (Lymph-ICF): Reliability and validity. Physical Therapy 91: 944-957.

DiSipio T, Rye S, Newman B, Hayes S 2013 Incidence of unilateral arm lymphoedema after breast cancer: A systematic review and meta-analysis. Lancet Oncology 14: 500-515.
Ferlay J, Soerjomataram I, Dikshit R, Eser S, Mathers C, Rebelo M, Parkin DM, Forman D, Bray F 2015 Cancer incidence and mortality worldwide: Sources, methods and major patterns in GLOBOCAN 2012. International Journal of Cancer 136: E359-E386.

Ferlay J, Steliarova-Foucher E, Lortet-Tieulent J, Rosso S, Coebergh JW, Comber H, Forman D, Bray F 2013 Cancer incidence and mortality patterns in Europe: Estimates for 40 countries in 2012. European Journal of Cancer 49: 1374-1403.

Fu MR, Kang Y 2013 Psychosocial impact of living with cancer-related Lymphedema. Seminars in Oncology Nursing 29: 50-60.

Hayes SC, Janda M, Cornish B, Battistutta D, Newman B 2008 Lymphedema secondary to breast cancer: how choice of measure influences diagnosis, prevalence, and identifiable risk factors. Lymphology 41: 18-28.

Hayes SC, Johansson K, Stout NL, Prosnitz R, Armer JM, Gabram S, Schmitz KH 2012 Upper-body morbidity after breast cancer. Incidence and evidence for evaluation, prevention, and management within a prospective surveillance model of care. Cancer 118(Issue Supplement S8): 2237-2249.

Hidding JT, Beurskens CH, Van Der Wees PJ, Van Laarhoven HW, Mw N-VDS 2014 Treatment related impairments in arm and shoulder in patients with breast cancer: A systematic review. Plos One 9: e96748.

Hjermstad MJ, Fayers PM, Haugen DF, Caraceni A, Hanks GW, Loge JH, Fainsinger R, Aass N, Kaasa S 2011 Studies comparing numerical rating scales, verbal rating scales, and visual analogue scales for assessment of pain intensity in adults: A systematic literature review. Journal of Pain and Symptom Management 41: 1073-1093.

International Society of Lymphology 2013 The diagnosis and treatment of peripheral lymphedema: 2013 consensus document of the International Society of Lymphology. Lymphology 46: 1-11.

Kostanoglu A, Hosbay Z, Tarak E 2016 Lymphoedema functioning, disability and health questionnaire Turkish version: Translation, cross-cultural adaptation and validation. Journal of Physical Therapy Science 28: 1728-1732.

Lietzen LW, Sørensen GV, Ording AG, Garne JP, Christiansen P, Nørgaard M, Jacobsen J 2011 Survival of women with breast cancer in central and northern Denmark, 1998-2009. Clinical Epidemiology 3(Suppl 1): 35-40.

Mokkink LB, Terwee CB, Patrick DL, Alonso J, Stratford PW, Knol DL, Bouter LM, De Vet HC 2010 The COSMIN checklist for assessing the methodological quality of studies on measurement properties of health status measurement instruments: an international Delphi study. Quality of Life Research 19: 539-549.

Morgan PA, Franks PJ, Moffatt CJ 2005 Health-Related Quality of Life with Lymphoedema: A Review of the Literature International Wound Journal 2: 47-62.

Organization WH 2013 How to use the ICF: A practical manual for using the International Classification of Functioning, Disability and Health (ICF). Exposure draft for comment. http://www.who.int/classifications/drafticf practicalmanual2.pdf?ua=1. Accessed 13 Feb 2016.

Pallant J 2010 SPSS Survival Manual: A Step by Step Guide to Data Analysis Using SPSS (4th ed). Berkshire, Open University Press. 
Rockson SG, Rivera KK 2008 Estimating the Population Burden of Lymphedema. Annals of the New York Academy of Sciences 1131: 147-154.

Terwee CB, Bot SD, De Boer MR, Van Der Windt DA, Knol DL, Dekker J, Bouter LM, De Vet HC 2007 Quality criteria were proposed for measurement properties of health status questionnaires. Journal of Clinical Epidemiology 60: 3442.

Tryggvadóttir L, Gislum M, Bray F, Å K, Hakulinen T, Storm $\mathrm{HH}$, Engholm G 2010 Trends in the survival of patients diagnosed with breast cancer in the Nordic countries 1964-2003 followed up to the end of 2006. Acta Oncologica 49: 624-631.

Vassard D, Olsen MH, Zinckernagel L, Vibe-Petersen J, Dalton SO, Johansen C 2010 Psychological consequences of lymphoedema associated with breast cancer: A prospective cohort study. European Journal of Cancer 46: 32113218.

Viehoff PB, Hidding JT, Heerkens YF, Van Ravensberg CD, Neumann HA 2013 Coding of meaningful concepts in lymphedema-specific questionnaires with the ICF. Disability and Rehabilitation 35: 2105-2112.

Wild D, Grove A, Martin M, Eremenco S, McElroy S, VerjeeLorenz A, Erikson P 2005 ISPOR task force for translation and cultural adaptation. Principles of Good Practice for the Translation and Cultural Adaptation Process for PatientReported Outcomes (PRO) Measures: Report of the ISPOR Task Force for Translation and Cultural Adaptation. Value in Health 8: 94-104.

Willis GB, Caspar R, Lessler J 1999 Cognitive Interviewing. A "How To" Guide. Reducing Survey Error through Research on the Cognitive and Decision Processes in Surveys, pp.141. Research Triangle Park,NC, Triangle Institute.

Willis GB, Jr AR A 2013 What do our respondents think we're asking? Using cognitive interviewing to improve medical education surveys. Journal of Graduate Medical Education 5: 353-356.

Willis GB, Miller K 2011 Cross-cultural cognitive interviewing: seeking comparability and enhancing understanding. Field Methods 23: 331-341. 


\section{Appendix}

\section{LYMFØDEM - FUNKTIONSNEDSAETTELSER, AKTIVITETS- OG DELTAGELSESBEGRANSNINGER SPФRGESKEMA (LYMPH-ICF-DK)}

Fornavn og efternavn:

Dato:

En hævelse i arm og/eller hånd kan udover fysiske og psykiske følger også indebære en del begrænsninger i udførelse af daglige gøremål og problemer med at klare hverdagen.

Dette spørgeskema indeholder 29 spørgsmål, der er udarbejdet på baggrund af information fra personer, der har samme tilstand som dig.

\section{Information om hvordan du udfylder spørgeskemaet}

Efter hvert spørgsmål er der en skala med tal fra 0 til 10. Tallet "0" yderst til venstre på skalaen angiver, at du overhovedet ikke har problemer med det, som spørgsmålet handler om, mens tallet "10" yderst til højre på skalaen angiver, at du har meget svære følger eller alvorlige begrænsninger på grund af hævelse i din arm. For hvert spørgsmål skal du sætte en cirkel om det tal mellem 0 og 10, der stemmer bedst overens med de følger eller begrænsninger, som du har på grund af hævelse i armen (se eksempel 1 og 2). Hvis et gøremål eller en aktivitet ikke er relevant for dig, skal du sætte et kryds i cirklen "Ikke relevant" (se eksempel 2).

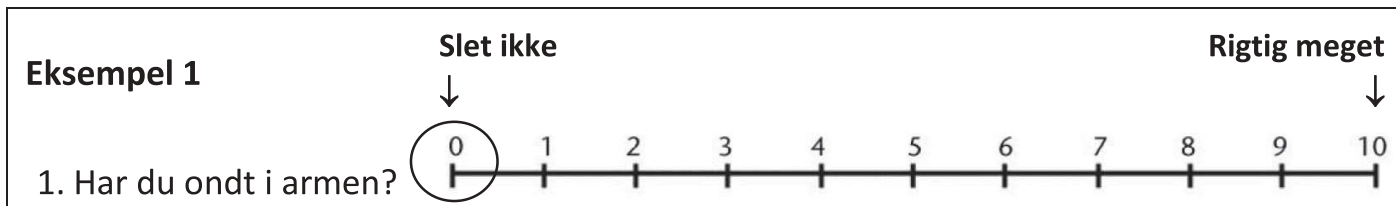

Hvis du slet ikke har ondt i armen, sætter du en cirkel om tallet " 0 "

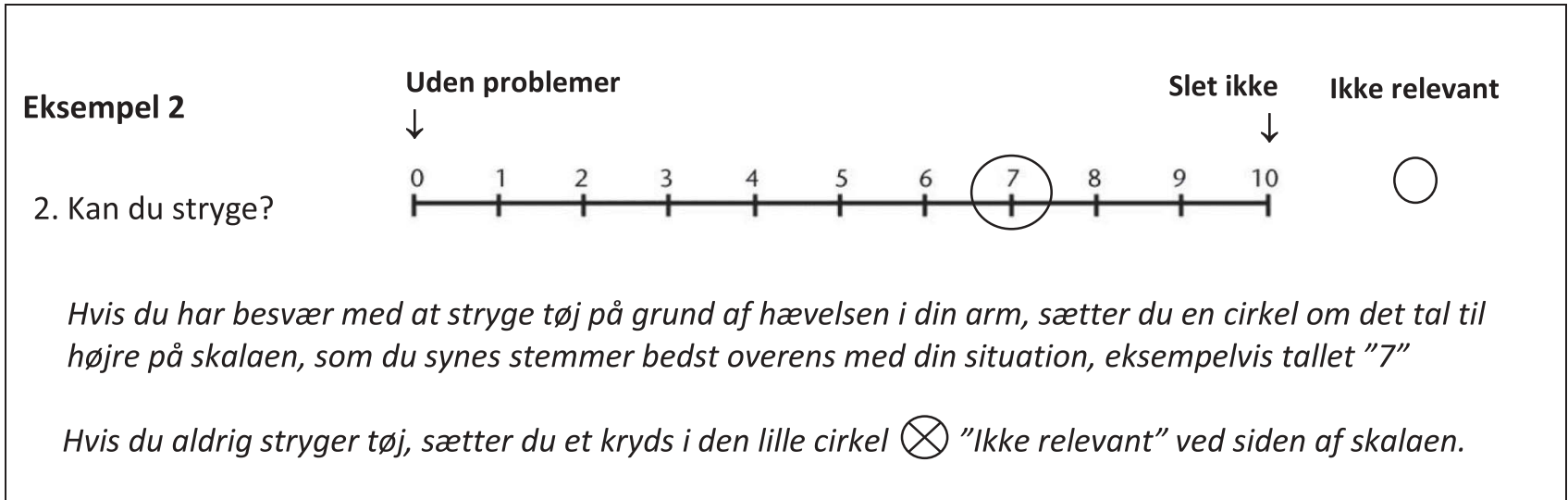

Vælg det svar, der stemmer bedst overens med din egen situation i forhold til armen inden for de seneste 2 uger. Brug ikke for lang tid til at tænke over hvert spørgsmål, og forsøg at besvare ALLE spørgsmål.

Dette spørgeskema er personligt, hvilket betyder, at du selv udfylder det. Fors $\emptyset \mathrm{g}$ at undlade at drøfte spørgsmålene med andre i din umiddelbare nærhed. 
Smerter samt immunforsvarets, bevægeapparatets og hudens funktion

Føles din arm:

1. tung (træt) ?

2. stiv?

3. hævet?

Har du:

4. nedsat styrke i armen?

5. prikkende fornemmelser i armen?

6. ondt i armen?

7. Føles huden på din arm spændt?
Slet ikke

Rigtig meget

$\downarrow$
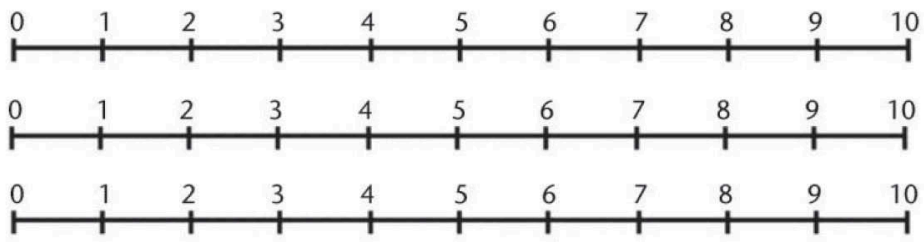

Slet ikke

Rigtig meget

$\downarrow$
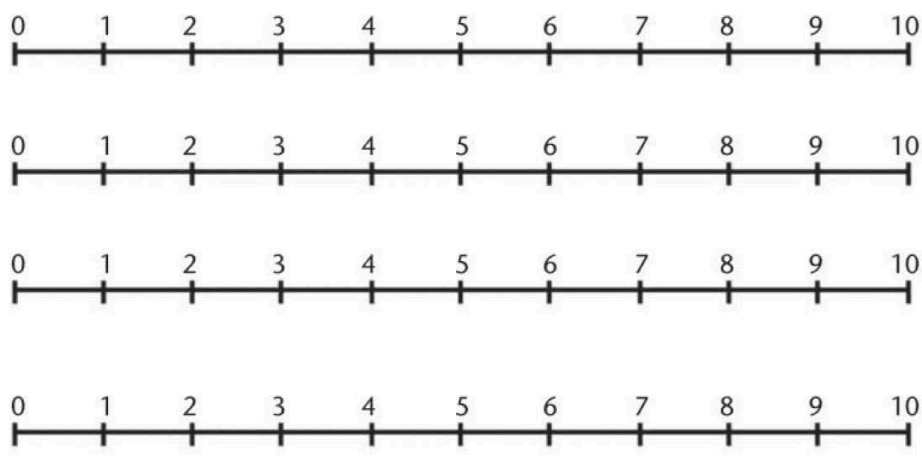

\section{Mentale funktioner}

Medfører problemerne med din arm,

at du:

8. føler dig trist?

9. føler dig modløs?

10. mangler selvtillid?

11. føler dig anspændt?
Slet ikke

$\downarrow$
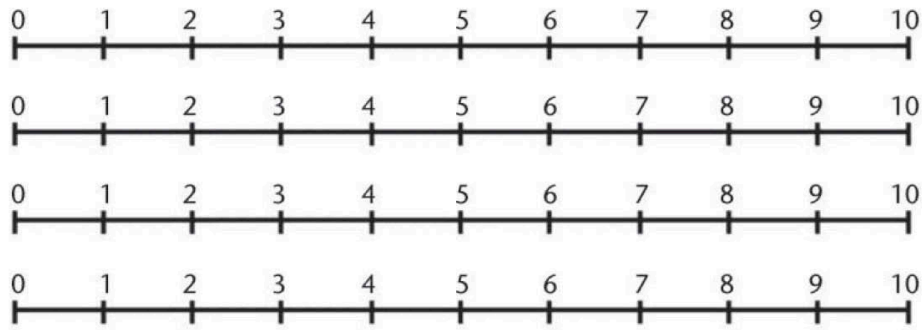

\section{Husholdning}

I hvilket omfang kan du:

12. gøre rent? (fx tørre støv af, st $\varnothing$ vsuge, vaske gulv)

$\downarrow$

Uden problemer

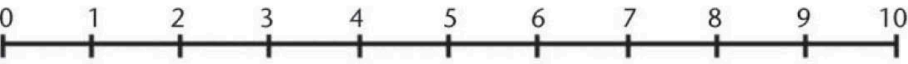

Ikke relevant $\downarrow$

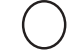

13. lave mad?

14. stryge?
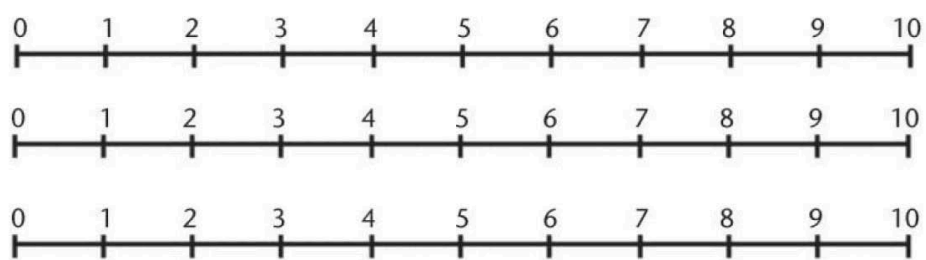

15. udføre havearbejde? 


\section{Bevægelse og færden}

I hvilket omfang kan du:

16. arbejde med armen over hovedhøjde ( $f x$. hænge vasket $\varnothing$ j op)?

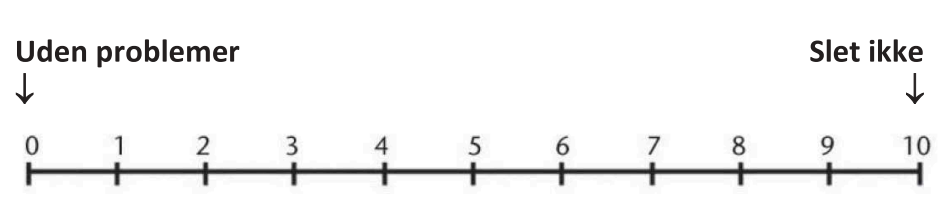

17. Iøfte eller bære tunge ting ( $f x$. en fyldt spand

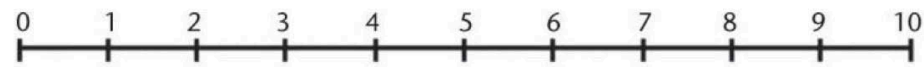
eller indkøbsposer)?

18. sove på den ramte side?

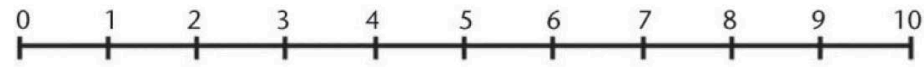

19. arbejde ved computer

(over $30 \mathrm{~min}$.)?

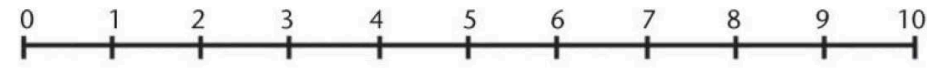

20. tage solbad?

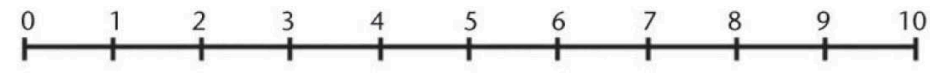

21. køre bil?

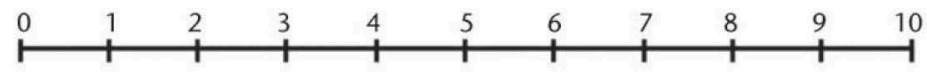

22. gå (over $2 \mathrm{~km}$ )?

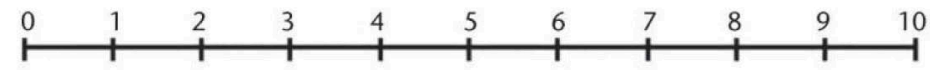

23. cykle?

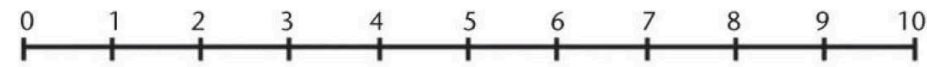

\section{Vigtige livsområder og socialt liv}

I hvilket omfang kan du:

24. tage på ferie?

25. dyrke dine hobbyer?

26. dyrke sport?

27. gå i det $t \varnothing j$, som du har lyst til?

28. udføre dit arbejde?

29. deltage i sociale aktiviteter med venner (fx. deltage i fester, gå til koncerter, gå på restaurant)?
Uden problemer

$\downarrow$

Slet ikke
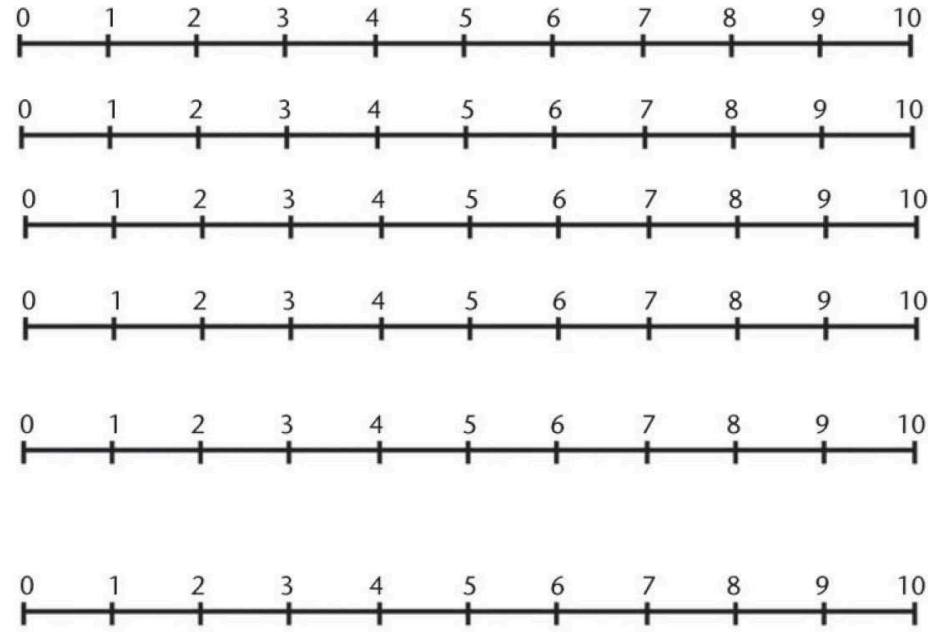

Ikke

relevant

$\downarrow$

0

0

0

0

0

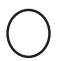

